\title{
Chickpea Protein Isolation, Characterization and Application in Muffin Enrichment
}

\author{
Sobhy A. El Sohaimy ${ }^{a} c^{*}$, Marageta A. Brennan $^{\mathrm{b}}$, Amira M. G. Darwish ${ }^{\mathrm{a}}$, And \\ Charles S. Brennan ${ }^{b}$ \\ ${ }^{a}$ Food Technology Department, Arid Lands Cultivation Research Institute, City of Scientific Research and \\ Technological Applications, 21934 Alexandria, Egypt. \\ b Wine, Food and Molecular Biosciences Department, Faculty of Agriculture and Life Sciences, Canterbury, \\ New Zealand \\ ${ }^{c}$ Department of Technology and Organization of Public Catering, Institute of Sport, Tourism and Service, \\ South Ural State University, 454080 Chelyabinsk, Russian Federation \\ ${ }^{*}$ Corresponding author \\ selsohaimy@srtacity.sci.eg \\ TEL.: +2034593420 \\ FAx: +2034593423
}

Received: 31 August 2018; Published online: 24 February 2021

\begin{abstract}
The aim of this study was to enhance the nutritional value and the functional characteristics of muffins by enriching with chickpea protein isolate, while keeping their rheological characteristics. Chickpea Protein isolate (CPI) was prepared by alkaline solubilization ( $\mathrm{pH} 11)$, followed by isoelectric precipitation at $\mathrm{pH}$ 4.5. SDS-PAGE revealed three subunits with molecular weights of 47,30 and $85 \mathrm{kDa}$; representing the globulin fractions, legumin-like and vicilin-like proteins. Maximum protein solubility $(83.32 \%)$ was obtained at $\mathrm{pH} 11$. CPI exhibited an emulsifying activity index of $25.17 \mathrm{~m}^{2}$ $\mathrm{g}^{-1}$, emulsion stability index of $14.09 \mathrm{~min}$. The foaming capacity and stability were $62 \%$ and $94.49 \%$, respectively. Water and oil absorption were 3.65 and $2.30 \mathrm{~mL} \mathrm{~g}^{-1}$, respectively. CPI was added to muffin batter at $0,2.5,5,7.5$ and $10 \%$. CPI fortified muffins showed reduction in moisture content, which influenced texture profile analysis through increasing hardness, gumminess and chewiness values. Additionally, both protein content and protein digestibility of muffins increased to 22.2 and $94.08 \%$, respectively. CPI-enriched muffins were darker (lower L) with yellowish crumbs (higher b). Finally, preliminary sensory evaluation showed high consumer acceptance for CPI-enriched muffins.
\end{abstract}

Keywords: Chickpea proteins isolate; Enriched muffins; In-Vitro Protein digestibility; Colour analysis; Texture Profile Analysis; Sensory evaluation

\section{Introduction}

Consumers throughout the world enjoy baked food products, especially muffins, due to their organoleptic characteristics (Gao, Brennan, Mason \& Brennan, 2016, 2017). Their high-level consumption makes them useful as potential carriers of bioactive compounds. Recently, consumers appreciate improvements in product flavor but they do not neglect their health benefits (Valmorida \& Castillo-Israel, 2018; Wardy et al., 2018). Chickpeas (Cicer arietinum L.) are an oldworld pulse and were first grown in the Levant and ancient Egypt. They have a nutlike flavor and are used to complement grains (such as whole grains); to form a complete protein. The protein 
quality of legumes such as chickpeas are significantly improved by heat treatment since heat destroys and/or inactivates anti-nutritional factors. Therefore, this might be important for vegans, individuals adhering to variations of plant based diets or low socio-economic individuals (O'Neil, Nicklas \& Fulgoni III, 2014; Wallace, Murray \& Zelman, 2016). Like other legumes, chickpea's albumins and globulins represent the two major protein fractions. The albumin fraction constitutes up to $15-25 \%$ whereas the globulins, represented mainly by vicinin and legumin, reach up to $60-80 \%$ of the extractable proteins. Albumins display a higher nutritive value due to their high content of lysine and sulfur amino acids. Chickpea proteins are appreciated due to their high biological value, well balanced amino acid content and low content of anti-nutritional factors. However, there have been concerns about chickpea protein isolates due to their low fat content among other reasons (Aloweidat, 2014; Carbonaro, Cappelloni, Nicoli, Lucarini \& Carnovale, 1997). Earlier researchers have investigated the physicochemical properties of chickpea protein isolates and their use in food enrichment as a dietetic alternative for individuals with special caloric or metabolic requirements (Aguilar \& Vélez-Ruiz, 2016). Herein, this study aims to enrich muffins with chickpea isolate proteins to potentially increase their nutritional and functional qualities while preserving rheological characteristics.

\section{Materials and Methods}

\section{$2.1 \quad$ Raw materials}

Organic chickpea flour (Cicer arietinum L.) (aka Besan flour, ACO, Australia); 25\% protein, 4.5\% fat and $9.7 \%$ moisture. The ingredients used for muffin preparation are: wheat flour (Chantal, NZ); $10.5 \%$ protein, $1.4 \%$ fat and $70.1 \%$ carbohydrates, skimmed milk powder (Go Milk, NZ); $8.3 \%$ protein, $0.3 \%$ fat, $13.8 \%$ carbohydrates, $125 \mathrm{mg}$ sodium and $300 \mathrm{mg}$ calcium, margarine from (Anchor, NZ); protein $<1.0 \mathrm{~g}$, fat $2 \mathrm{~g}$, carbohydrates $<1 \mathrm{~g}$ and sodium $24 \mathrm{mg}$, sugar (Chelsea White sugar NZ), baking powder (Edmonds, NZ), and salt (Essentials, Australia). All ingredients were obtained from local markets located in Christchurch, New Zealand.

\subsection{Preparation of defatted chickpea flour}

Defatting of chickpea flour was carried out according to Folch, Lees and Stanley (1957) with some modifications. The chickpea samples were homogenized in chloroform/methanol (v/v; 2/1); the final volume was 20 fold the sample volume ( $1 \mathrm{~g}$ in $20 \mathrm{ml}$ of solvent mixture). After dispersion, the whole mixture was agitated for $60 \mathrm{~min}$ in an orbital shaker at room temperature. Then, the homogenate was filtered with a folded filter paper to recover the liquid phase. Finally, the chickpea flour was dried at $43^{\circ} \mathrm{C} / 36 \mathrm{~h}$ in a hot air flow.

\subsection{Preparation of chickpea protein isolate}

The chickpea protein isolate was prepared according to Chang, Alli, Konishi and Ziomek (2011), El-Sohaimy, Sitohy and El-Masry (2007). Fifty grams of defatted chickpea flour were suspended in $1000 \mathrm{~mL}$ deionized water $(1: 20, \mathrm{w} / \mathrm{v})$, the $\mathrm{pH}$ values varied in the range of 3.0 to 12.0 using $0.1 \mathrm{~N} \mathrm{NaOH}$ and $0.1 \mathrm{~N} \mathrm{HCl}$. The suspensions at different $\mathrm{pH}$ values were stirred for $1 \mathrm{~h}$ to assess optimum solubility. The soluble isolate fractions (at the desired $\mathrm{pH}$ ) were centrifuged at $6,000 \mathrm{x}$ g for $30 \mathrm{~min} 20^{\circ} \mathrm{C}$. The supernatant was collected and acidified to $\mathrm{pH}$ values ranging from 1 to 6 to facilitate protein precipitation and determine the isoelectric point. Precipitates were then centrifuged at $10,000 \mathrm{x}$ g for $45 \mathrm{~min}$ at $4^{\circ} \mathrm{C}$. The precipitated protein fractions were collected, neutralized and freeze dried. The total protein content in the isolates was determined by Kjeldahl method. 


\subsection{Characterization of chickpea protein isolate}

\section{Sodium Dodecyl Sulfate Polyacrylamide Gel Electrophoresis (SDS-PAGE)}

The protein isolate was dissolved in aqueous solution at six different concentrations $(0.015,0.03$, $0.062,0.125,0.5$ and $\left.1 \mathrm{mg} \mathrm{mL} \mathrm{mL}^{-1}\right)$ and applied to the gel for better resolution of the bands. SDS-PAGE was carried out by the technique reported by Laemmli (1970); using 4\% stacking gel and $12 \%$ separating gel. Sample solutions $(20 \mu \mathrm{L})$ were prepared by dissolving $10 \mathrm{mg}$ of freeze dried protein extract in $1 \mathrm{~mL}$ sample buffer [distilled water, $0.5 \mathrm{M}$ Tri $\mathrm{HCl}$ (pH 6.8), glycerol, SDS (10\%), bromophenol blue (1\%) and $\beta$-mercaptoethanol]. The samples were heated at $98{ }^{\circ} \mathrm{C}$ for $10 \mathrm{~min}$, then applied to the sample wells. The standard protein marker $(260,160$, $110,80,60,50,40,30,20,15,10$ and $3.5 \mathrm{KDa})$ (Bio-Rad Hercules, USA) was used for molecular weight estimation. Electrophoretic migration was monitored at constant current $(14 \mathrm{~mA} / \mathrm{gel})$ for 1.5 to $2 \mathrm{~h}$. Gels were fixed with a fixing solution [water/methanol/acetic acid, 700: 200: 100 $\mathrm{mL}$ ] for $30 \mathrm{~min}$ and then stained with commassie brilliant blue R-250 for $1 \mathrm{~h}$. The stained gels were destained by frequent change of the fixing solution.

\section{Protein solubility}

Chickpea protein isolate solubility (5\% suspension) was determined at $\mathrm{pH}$ values ranging from 1.0 to 12.0 according to Klompong, Benjakul, Kantachote and Shahidi (2007). For better solubilization, the suspensions were stirred at room temperature for $1 \mathrm{~h}$, using a magnetic stirrer. The $\mathrm{pH}$ values were adjusted using $\mathrm{HCl}(0.1 \mathrm{~N})$ and $\mathrm{NaOH}(0.1 \mathrm{~N})$. The suspensions at different $\mathrm{pH}$ values were centrifuged at $6,000 \mathrm{x} \mathrm{g}$ for 30 min. The total protein was determined in the supernatants by Kjeldahl method. Protein solubility $(P S)$ was calculated using the following equation. Samples were tested in triplicate.

$P S(\%)=\left(\frac{\text { Protein content in supernatant }}{\text { Total protein content in sample }}\right) \times 100$
A protein solubility curve was constructed by using the average of soluble protein percentage values calculated at each $\mathrm{pH}$ value.

\section{Functional properties of protein isolate}

\section{Emulsifying activity index (EAI) and emulsion stability index (ESI)}

EAI and ESI were measured using the method of Pearce and Kinsella (1978) with some modifications. Fifteen $\mathrm{mL}$ of $1 \%$ neutralized protein solution was mixed with $5 \mathrm{ml}$ of commercial sunflower oil. The mixture was homogenized at 7,500 rpm for $1 \mathrm{~min}$, using homogenizer (MZIP Model 114, China). Then, $50 \mu \mathrm{L}$ aliquots were taken from emulsions at 0 and $10 \mathrm{~min}$ from the bottom of the tube and mixed with $10 \mathrm{~mL}$ of $0.1 \%$ sodium dodecyl sulphate (SDS) (1:200 dilution). The absorbance of the diluted solutions was measured at $500 \mathrm{~nm}$ immediately after emulsion formation $\left(\mathrm{A}_{0}\right)$ and at $10 \mathrm{~min}\left(\mathrm{~A}_{10}\right)$. EAI and ESI were calculated using the following equations:

$$
\begin{gathered}
E A I \frac{m^{2}}{g}=\frac{2 T \times F \times A_{0}}{C \times \theta \times 10,000} \\
E S I=A_{0} \times \frac{\Delta t}{\Delta A} \\
\Delta A=A_{0}-A_{10} \text { and } \Delta t=10 \mathrm{~min}
\end{gathered}
$$

Where: $\mathrm{T}=2.303 ; \mathrm{F}$ : dilution factor $(200) ; \mathrm{A}_{0}$ : absorbance measured at $500 \mathrm{~nm}$ immediately after emulsion form ation; $\mathrm{A}_{t}$ : absorbance measured at $500 \mathrm{~nm}$ after $10 \mathrm{~min}$ of emulsion formation c: protein concentration $(0.01 \mathrm{~g} / \mathrm{mL})$ and $\theta$ : dispersed phase (oil) volume fraction (15).

\section{Foaming capacity (FC) and foaming stability (FS)}

FC and FS were assessed according to the method described by Tsutsui (1988) with some modifications. The protein solution was agitated in a blender at high speed (Breville, platinum, China) for 5 min and then transferred into graduated cylinders. Foam capacity was calculated according to following equation:

$$
F C(\%)=\left(\frac{V_{\text {after agitation }}-V_{\text {prior agitation }}}{V_{\text {prior agitation }}}\right) \times 100
$$


Similarly, FS value was determined, however samples were allowed to stand at room temperature for $30 \mathrm{~min}$ and the residual foam volume ( $V_{\text {Residual foam }}$ ) was calculated according to the following equation:

$$
F S(\%)=\left(\frac{V_{\text {Residual foam }}}{V_{\text {Total foam }}}\right) \times 100
$$

\section{Water and oil absorption}

The water/oil absorption capacity of chickpea protein isolate was determined by the method of Chandra and Samsher (2013). One gram of the isolate was mixed with $10 \mathrm{~mL}$ of distilled water/sunflower oil (specific gravity: 0.88) and allowed to stand at ambient temperature (30土 $2^{\circ} \mathrm{C}$ ) for $30 \mathrm{~min}$, then was centrifuged at 3,500 $\mathrm{x} \mathrm{g}$ for $30 \mathrm{~min}$. Water/oil absorption $(W O A)$ in $\mathrm{mg} / \mathrm{l}$ was calculated according to the equation:

$$
W O A=V_{\text {water (oil) Initial }}-V_{\text {supernatant }}
$$

\subsection{Batter and muffin preparation}

Four muffin batter formulations were prepared by replacing a percent of the wheat flour with chickpea protein isolate (CPI) according to Rahman, Hiregoudar, Veeranagouda, Ramachandra et al. (2015) with some modifications. The samples were identified as [control, M1 (CPI 2.5), M2 (CPI 5), M3 (CPI 7.5) and M4 (CPI 10)]. The recipes used for different muffin preparations were exhibited in (w/w \%) as shown in table 1. The ingredients were weighed using a kern 572 balance (Scout $^{\text {TM }}$ Pro SP602, OHAUS Corporations, USA). Egg and margarine were mixed in a laboratory scale kitchen mixer (Kitchen aid, St. Joseph, USA) at speed 4 then speed 8 for 10 and $50 \mathrm{~s}$, respectively. Flour, sugar, salt, milk powder and water were mixed at speed 2 for 10 $\mathrm{s}$, then speed 8 for $50 \mathrm{~s}$. Forty-five grams of batter was filled into paper cups in a muffin pan and baked in the oven (MIWE condo) at $180^{\circ} \mathrm{C}$ for 20 min. Baked muffins were left to cool at room temperature for $1 \mathrm{~h}$ in order to avoid moisture condensation on their undersurface, and finally packed in polypropylene bags and stored in a dry environment prior to analysis.

\subsection{Muffin characteristics}

Muffin properties (moisture content, height, specific volume and colour) were assessed following (Rahman, Hiregoudar, Veeranagouda, Ramachandra et al., 2015) procedures. Moisture content of different muffin recipes was determined according to AOAC (1990). Height was measured with a digital caliper, from the bottom to the highest point of the muffin. Specific volume was determined by milletseed displacement method and was expressed as specific volume $\left(\mathrm{cm}^{3} \mathrm{~g}^{-1}\right)$. Colour parameters were determined for muffin crust and crumb via Ultrascan VIS Hunter Lab (MiniScan XE Plus, Model 45/0-L, Hunter Associates Inc, Reston, VA, USA). Values were expressed by Hunter $(L$, $a$, and $b$ ) values which correspond, respectively, to: value of lightness (0-100 representing dark to light), value of redness and greenness degree (higher positive indicating more red) and value of yellowness and blueness degree (higher value indicating more yellow).

\subsection{Protein content and In-Vitro protein digestibility of muffins}

Total protein content of enriched muffins was determined by Kjeldahl method as described in AOAC (1990). One g of muffin sample was placed into a digestion flask, along with $15 \mathrm{~mL}$ of concentrated sulfuric acid $\left(\mathrm{H}_{2} \mathrm{SO}_{4}\right)$. Additionally, seven grams of potassium sulfate and a catalyst, usually copper, were added to the flask. The mixture was transferred to a digestion tube and boiled at $400^{\circ} \mathrm{C}$ using a heating block until formation of white fumes, then heating was continued for about 60-90 min. The tube was cooled then water $(250 \mathrm{~mL})$ was cautiously added. The $\mathrm{pH}$ of the mixture was raised using sodium hydroxide (45\% $\mathrm{NaOH}$ solution); this converts the ammonium $\left(\mathrm{NH}_{4}^{+}\right)$ions, which are dissolved in the liquid, to the ammonia gas $\left(\mathrm{NH}_{3}\right)$. The nitrogen has been separating away from the digestion mixture by distilling the ammonia (converting it to a volatile gas, by raising the temperature to boiling point). The distilled vapor has been trapped in a special trapping solution of about $15 \mathrm{~mL} \mathrm{HCl}$ in $70 \mathrm{~mL}$ of water, and then the trapping flask 
Characterization of Chickpea Protein Enriched Muffin |SI61

Table 1: Chickpea protein enriched muffin batter recipes (CPI, Chickpea Protein Isolate)

\begin{tabular}{llllll}
\hline Ingredients (w/w)\% & Control & M1 (CPI 2.5) & M2 (CPI 5) & M3 (CPI 7) & M4 (CPI 10) \\
\hline Wheat flour & 32.94 & 32.12 & 31.29 & 30.47 & 29.65 \\
Chickpea protein isolate & 0.00 & 0.82 & 1.65 & 2.47 & 3.29 \\
White sugar & 19.70 & 19.70 & 19.70 & 19.70 & 19.70 \\
Salt & 0.40 & 0.40 & 0.40 & 0.40 & 0.40 \\
Baking powder & 1.66 & 1.66 & 1.66 & 1.66 & 1.66 \\
Fat (margarine) & 16.46 & 16.46 & 16.46 & 16.46 & 16.46 \\
Skimmed milk powder & 2.49 & 2.49 & 2.49 & 2.49 & 2.49 \\
Liquid whole eggs & 9.89 & 9.89 & 9.89 & 9.89 & 9.89 \\
Water & 16.46 & 16.46 & 16.46 & 16.46 & 16.46 \\
\hline
\end{tabular}

was removed. As the ammonia dissolves in the acid trapping solution, it neutralizes some of the present $\mathrm{HCl}$. The excess $\mathrm{HCl}$ was then back titrated with a standard $\mathrm{NaOH}$. The indicator dye was added to the acid/ammonia trapping solution. In this way the amount of ammonia distilled off from the digestive solution could be calculated; this amount corresponds to the nitrogen content of the protein. The volume of sodium hydroxide solution was noted, and the nitrogen was calculated by the following equation:

$$
\begin{gathered}
\% N=\frac{(m l \text { standard acid }-m l \text { blank }) \times N \text { of acid } \times 1.4007}{\text { weight of sample in grams }} \\
\% P=\% N X 5.7
\end{gathered}
$$

In-vitro protein digestibility was carried out for CPI-enriched muffins by the multienzyme method of Bodwell, Satterlee and Hackler (1980), Carbonaro et al. (1997). Porcine pancreatic trypsin (type IX, 15310 units/mg protein), bovine pancreatic chymotrypsin (type II, 48 units/mg of solid), porcine intestinal peptidase (P-7500, 115 units/g of solid) and bacterial protease (type XIV, 4.4 units /mg of solid) (Sigma-Aldrich, Germany) were employed for the enzymatic digestion. In-vitro protein digestibility was calculated according to the equation:

$$
Y=234.84-22.56 X
$$

Where, $\mathrm{Y}$ is the In-vitro digestibility of protein (\%) and $\mathrm{X}$ is the $\mathrm{pH}$ of the suspension after 20 min of digestion.

\subsection{Texture Profile Analysis (TPA) of muffins}

The texture profile analysis was carried out using texture analyzer (TA/TX-plus texture analyzer; Texture analyzer, Stable Micro system, Surrey, UK) equipped with a 5-kg load cell. Exponent software was used for testing procedures, presentation formats and data analysis to provide the most powerful and flexible testing analysis solution available. The muffin samples were placed at the center of a heavy-duty platform (HD P/90), and subjected to compression (50\%) using a 75 $\mathrm{mm}$ diameter flat aluminum probe $(\mathrm{P} / 75)$ at test speed of $1 \mathrm{~mm} / \mathrm{s}$. Firmness is the maximum peak force during the first compression cycle. Springiness (the height that the muffin sample recovered during the time elapsed between the end of the first compression and the start of the second one) and cohesiveness (the ratio of the peak area during the second compression to the one during the first compression) were calculated from the force time curve (Bourne, 2002).

\subsection{Sensory evaluation}

Ten well trained panelists from staff members of Food Technology Department, City of Scientific Research, and Technological Applications, Alexandria, Egypt carried out preliminary sensory evaluation of enriched muffins. Samples were randomly assigned to each panelist. The panelists were asked to evaluate each sample: shape, mouth feel, flavour, crumb texture, crumb col- 
our, crust colour and crust texture, through a nine point hedonic scale according to (Ihekoronye \& Ngoddy, 1985). The ratings are: Dislike extremely (1), Dislike very much (2), Dislike moderately (3), Dislike slightly (4), Neither like nor dislike (5) Like slightly (6) Like moderately (7), Like very much (8) and Like extremely (9).

\subsection{Statistical analysis}

Statistical factorial analysis was performed using analytical software SPSS ${ }^{\circledR} 13.0$ (Statistical Package for the Social Sciences, 2005). Differences were considered significant at $\mathrm{P}<0.05$.

\section{Results and Discussion}

\subsection{Chickpea protein isolate average yield}

Protein isolates from chickpea defatted flour were prepared in two steps: the first was the solubilization and extraction of protein from chickpea flour at alkaline $\mathrm{pH}$. The optimum $\mathrm{pH}$ for the extraction of maximum amount of protein was 11; maximum chickpea protein extraction rate was $80 \%$. The protein was precipitated at isoelectric point ( $\mathrm{pH} 4.5$ ), which recovered maximum soluble protein $(78 \%)$, as described by El-Sohaimy et al. (2007). Extraction of chickpea protein reached a recovery percent of $82.94 \%$ yield.

\subsection{Characterization of chickpea protein isolate}

\section{Protein profile}

Figure 1 illustrates the SDS-PAGE profiles of six different concentrations of chickpea protein isolate $(0.015,0.03,0.062,0.125,0.5$ and $1 \mathrm{mg}$ $\left.\mathrm{ml}^{-1}\right)$. SDS-PAGE gel analysis revealed that the chickpea protein profiles were composed mainly of three bands; the major protein subunit (MW $47 \mathrm{kDa}$ ), followed by a $30 \mathrm{KDa}$ protein and finally an $85 \mathrm{kDa}$ protein. Similar observation was reported by Papalamprou, Doxastakis and Kiosseoglou (2010), who stated that these protein constituents belong to the globulin fractions, legumin like and vicilin like proteins. Different concentrations aid the confirmation of band positions with increased intensity at higher concentrations.

\section{Proteins solubility}

The solubility of isolated proteins at different $\mathrm{pH}$ values is presented in figure 2. A sharp minimum solubility (24.92 and $28.65 \%$ ) was observed at acidic $\mathrm{pH}$ values (4 and 5). On the other hand, the protein isolate showed the highest protein solubility at pH 11 (83.32 \%). This observation illustrates that the major isolated chickpea proteins are acidic and are soluble in alkaline medium. The protein solubility profile is similar to those reported for several legume proteins in earlier studies (Carbonaro et al., 1997; Liu, Hung \& Bennett, 2008). These results suggest that alkaline medium, $\mathrm{pH} \mathrm{11,} \mathrm{is} \mathrm{the} \mathrm{optimum} \mathrm{pH}$ for solubilization of most chickpea proteins.

\subsection{Functional properties of protein isolate}

Functionality is any property of a food ingredient, except its nutritional values, that has a great impact on its utilization. Chickpea protein isolate functional properties are presented in table 2 .

\section{Emulsifying activity index (EAI) and emulsion stability index (ESI)}

EAI and ESI were determined for the chickpea protein isolate to support its applications in food industry. Table 2 shows the EAI and ESI of chickpea protein isolate. Chickpea protein isolate exhibited EAI and ESI values of $25.17 \pm 0.07 \mathrm{~m}^{2} / \mathrm{g}^{-1}$ and $14.09 \pm 0.40 \mathrm{~min}$, respectively. Several studies have reported the emulsifying properties of chickpea protein isolate (Alvarez, Cuesta, Herranz \& Canet, 2017; Ladjal-Ettoumi, Boudries, Chibane \& Romero, 2016). To form emulsions, proteins migrate to the oil-water interface and re-align to allow positioning of hydrophobic groups towards the oil phase and hydrophilic groups towards the aqueous phase. Reducing interfacial tension between oil and water phases enables emulsion 


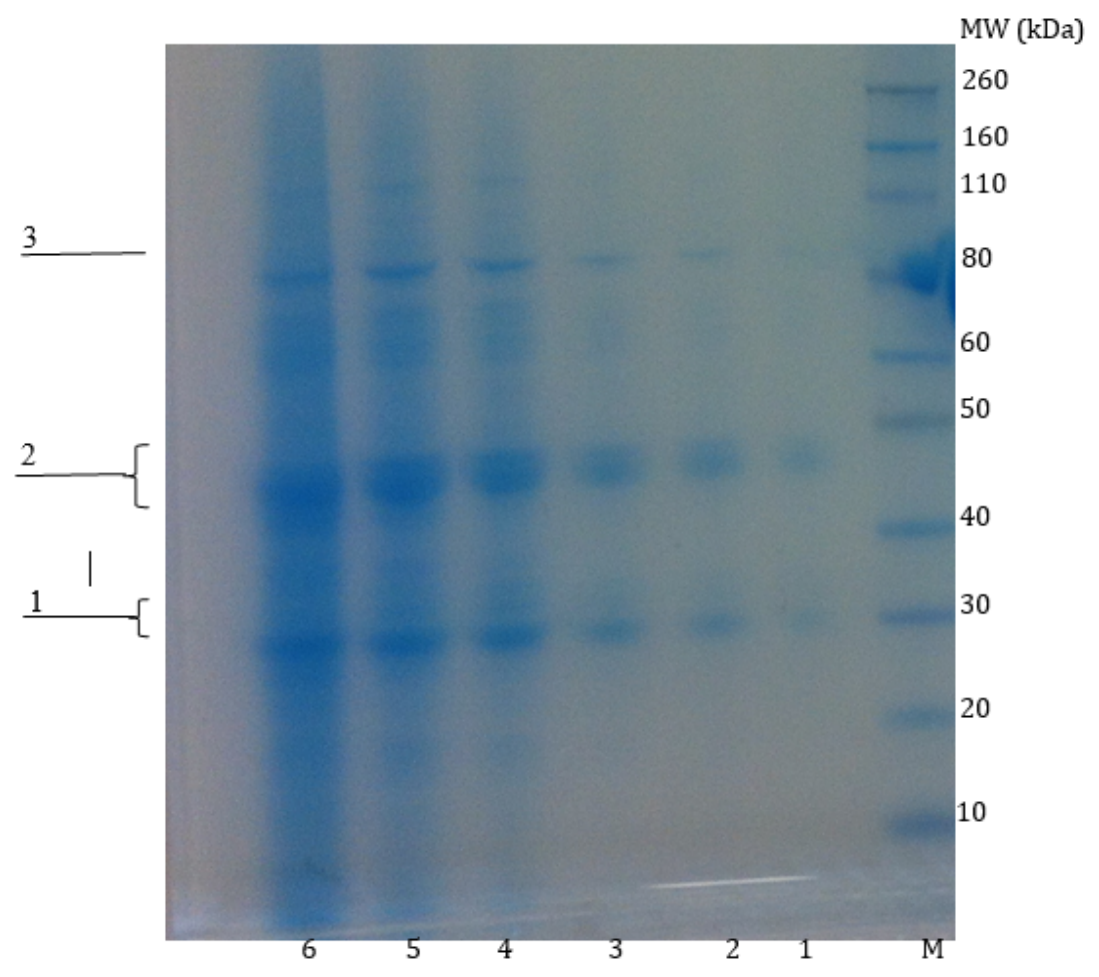

Figure 1: SDS-PAGE for Chickpea Protein Isolate Lane M: protein marker; Lane 1: $0.015 \mathrm{mg} \mathrm{ml}^{-1}$; lane 2: $0.03 \mathrm{mg} \mathrm{mL}^{-1}$; lane 3: $0.062 \mathrm{mg} \mathrm{mL}^{-1}$; lane 4: $0.125 \mathrm{mg} \mathrm{mL}^{-1}$; lane $5: 0.5 \mathrm{mg} \mathrm{mL}^{-1}$ and lane 6: $1 \mathrm{mg} \mathrm{mL}^{-1}$

Table 2: Chickpea protein isolate functional properties

\begin{tabular}{lll}
\hline Parameter & Unit & Value \\
\hline Emulsifying activity index (EAI) & $\mathrm{m}^{2} \mathrm{~g}^{-1}$ & $25.17 \pm 0.07$ \\
Emulsion stability index (ESI) & $\mathrm{min}$ & $14.09 \pm 0.40$ \\
Foaming capacity (FC) & $\%$ & $62.00 \pm 2.83$ \\
Foaming stability (FS) & $\%$ & $94.49 \pm 1.67$ \\
Water absorption & $\mathrm{mlg}^{-1}$ & $3.65 \pm 0.07$ \\
Oil absorption & $\mathrm{mlg}^{-1}$ & $2.30 \pm 0.14$ \\
\hline \hline Data presented as mean \pm SD (samples were run in duplicate)
\end{tabular}

IJFS | February $2021 \mid$ Volume $10 \mid$ pages SI57-SI71 
SI64 El-Sohaimy et al.

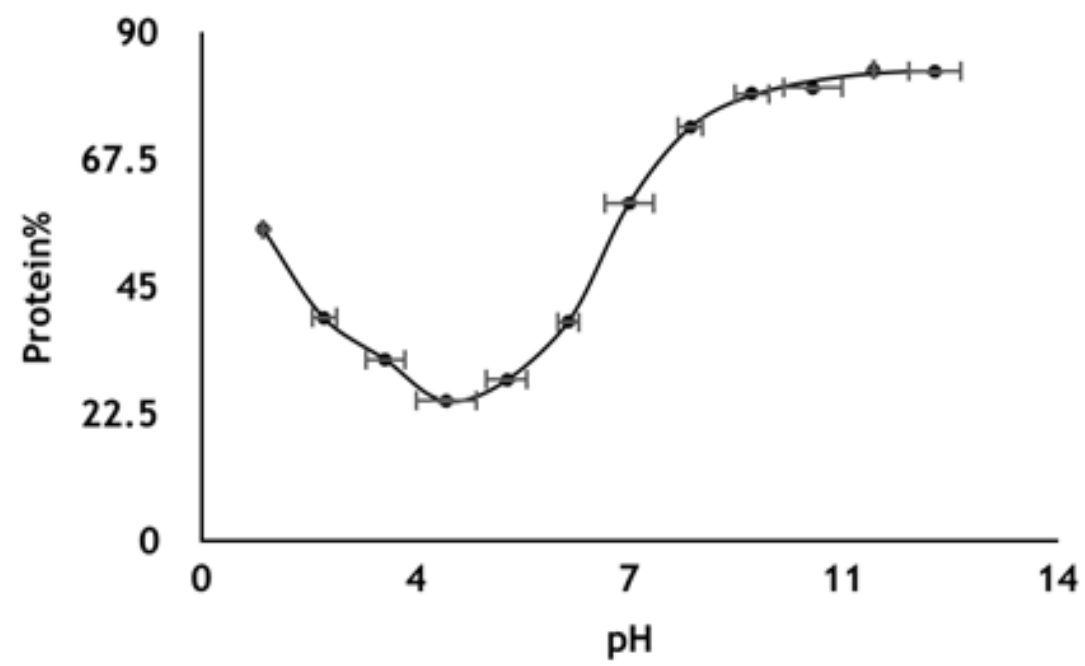

Figure 2: Chickpea protein isolate solubility profile. Data presented as the mean $\pm \mathrm{SD}$ value (samples were run in triplicate)

droplets to form, which subsequently leads to higher emulsion stability (Johnston, Nickerson \& Low, 2015).

\section{Foaming properties (Foaming capacity and foaming stability)}

Foam capacity and foam stability of chickpea protein isolate are shown in table 2. The protein isolate showed foam capacity of $62.00 \pm 2.83$ $\%$, which might be related to the presence of globulin fractions, which can encapsulate and retain air. Therefore, rapid migration, unfolding and rearranging of the air-water interface are necessary to exhibit good foam capacity (Alleoni, 2006). On the other hand, chickpea showed relatively high foaming stability $(94.49 \pm 1.67 \%)$, based on air retaining, which could support its recommendation in food industries, such as bakery products and ice creams. Similar foaming properties of chickpea proteins have been reported earlier by Boye et al. (2010).

\section{Water and oil absorption}

The water/oil absorption properties of chickpea protein isolate are shown in table 2. The isolated protein showed water and oil absorption of $3.65 \pm 0.07$ and $2.30 \pm 0.14 \mathrm{~mL} / \mathrm{g}$ respectively. These values are similar to those previously reported by Aloweidat (2014), who also reported that oil absorption capacity of protein is partially related to the physical confinement of oil by means of the protein matrix. Therefore, the source of the protein might be important.

\subsection{Characteristics of muffins enriched with chickpea protein}

The moisture content, colour, height and volume properties of baked CPI-enriched muffins are illustrated in tables 3 and 4 . Enrichment of muffins with chickpea protein caused a reduction in moisture content of fortified muffins compared to control, and this reduction correlates with the increase in CPI concentration. However, this decrease was not significant in the first two blends (CPI 2.5 and CPI 5.0\%). Rahman, 
Characterization of Chickpea Protein Enriched Muffin |SI65

Table 3: Properties of chickpea protein enriched muffins

\begin{tabular}{lccc}
\hline Sample & $\begin{array}{c}\text { Moisture } \\
(\%)\end{array}$ & $\begin{array}{c}\text { Height } \\
\mathbf{( m m )}\end{array}$ & $\begin{array}{c}\text { SP. Volume } \\
\left.\mathbf{( c m}^{3} \mathbf{g}^{-1}\right)\end{array}$ \\
\hline Control & $23.05 \pm 2.05^{a}$ & $42.11 \pm 1.80^{c}$ & $92.00 \pm 4.00^{a}$ \\
M1 (PI 2.5) & $22.95 \pm 1.03^{a}$ & $43.42 \pm 1.69^{a}$ & $88.00 \pm 2.00^{c}$ \\
M2 (PI 5) & $22.75 \pm 0.62^{a}$ & $42.75 \pm 0.51^{b}$ & $90.00 \pm 3.06^{b}$ \\
M3 (PI 7.5) & $21.83 \pm 1.28^{b}$ & $43.08 \pm 0.25^{a b}$ & $92.00 \pm 2.00^{a}$ \\
M4 (PI 10) & $21.41 \pm 1.02^{c}$ & $40.11 \pm 0.64^{d}$ & $33.00 \pm 1.16^{a}$ \\
\hline
\end{tabular}

Data presented as mean \pm SD (samples were run in triplicate), Mean in the same column followed by different superscript letters are significantly different $(\mathrm{p}>0.05)$

Table 4: Colour properties of chickpea protein enriched muffins

\begin{tabular}{lcccccc}
\hline \multirow{2}{*}{ Sample } & \multicolumn{2}{c}{ L } & \multicolumn{2}{c}{ A } & \multicolumn{2}{c}{ b } \\
& Crust & Crumb & Crust & Crumb & Crust & Crumb \\
\hline Control & $64.03 \pm 0.85^{a}$ & $80.24 \pm 1.59^{b}$ & $16.92 \pm 0.75^{b}$ & $3.58 \pm 0.17^{c}$ & $45.24 \pm 0.87^{a}$ & $29.90 \pm 0.56^{e}$ \\
M1 (CPI 2.5) & $62.23 \pm 2.13^{c}$ & $80.15 \pm 1.41^{b}$ & $17.65 \pm 0.81^{a}$ & $3.94 \pm 0.50 \mathrm{bc}$ & $44.51 \pm 1.02^{b}$ & $31.06 \pm 0.94^{d}$ \\
M2 (CPI 5) & $63.12 \pm 1.76^{b}$ & $80.74 \pm 2.24^{a}$ & $16.07 \pm 2.65^{c}$ & $4.11 \pm 0.08^{b}$ & $43.88 \pm 1.31^{c}$ & $32.83 \pm 0.42^{c}$ \\
M3 (CPI 7.5) & $55.03 \pm 3.15^{e}$ & $78.51 \pm 1.09^{c}$ & $16.41 \pm 0.49^{c}$ & $4.85 \pm 0.06^{b c}$ & $41.07 \pm 2.09^{e}$ & $33.68 \pm 0.70^{b}$ \\
M4 (CPI 10) & $56.95 \pm 2.42^{d}$ & $77.84 \pm 0.76^{d}$ & $16.79 \pm 0.63^{b}$ & $4.87 \pm 0.20^{a}$ & $42.54 \pm 2.12^{d}$ & $34.82 \pm 0.43^{a}$ \\
\hline
\end{tabular}

Data presented as mean \pm SD (samples were run in duplicate), Means in the same column followed by different superscript letters are significantly different $(\mathrm{p}>0.05) \mathrm{CPI}=$ Chickpea protein isolate Colour parameters by Ultrascan VIS Hunter Lab (MiniScan XE Plus, Model 45/0-L, Hunter Associates Inc, Reston, VA, USA). $L$, $a$, and $b$ represent: value of the lightness (0-100 representing dark to light), value of redness and greenness degree (higher positive indicating more red) and value of yellowness and bluenessdegree (higher value indicating more yellow) respectively.

Hiregoudar, Veeranagouda, C T et al. (2015) reported similar behavior with increasing levels of enrichment in muffin batter. There was no significant variation in either the height or the specific volumes of the four enrichment treatments in comparison with the control, except for M1 (CPI 2.5\%) which showed a decrease in specific volume with a value close to control. These results could help to improve muffin quality (height and volume) like control muffins that consumers are familiar with. This emphasizes that the enrichment of muffins with chickpea protein didn't negatively affect the physical properties of the product. Colour characteristics of fortified muffins are presented in table 4. The colour properties were more pronounced in the crust compared to the crumb for all parameters and all combinations. Crusts tended to be darker (lower $\mathrm{L}$ values; 56.95 \pm 2.4 ), more reddish (higher values; $16.79 \pm 0.63$ ) and yellowish (lower b values; $42.54 \pm 2.12$ ) than crumbs. L (Lightness) results illustrate a significant impact of protein enrichment on the muffins. This is because the interaction between the ingredients during baking, possibly due to increasing of Millard browning reactions concurrent with higher protein enrichment percent, subsequently resulted in darker muffins in both crust and crumb. Similar observations have been recorded by Bhaduri (2013). Comparing the redness degree to control, the CPI enrichment did not cause high variations in crumb and crust despite their significance. The yellow colour of CPI affected the crumb colour, b values in the muffins increased with higher substi- 
tutions of CPI, however, $\mathrm{b}$ values decreased for the crust. This could be attributed to Millard reactions that might cause consumption of the protein amino acids and reducing sugars to produce a brown colour that diverts the tendency for lightness (to become darker) rather than yellowish. Generally, similar patterns were reported by Bhaduri (2013), (Rahman, Hiregoudar, Veeranagouda, C $\mathrm{T}$ et al., 2015) and (Wardy et al., 2018).

\subsection{Protein content and In-Vitro Protein Digestibility}

Figure 3 and 4 exhibits the protein content and in vitro protein digestibility of CPI-enriched muffins. Figure (3) shows a significant increase in protein content of enriched muffins compared to control, as a function of CPI concentration. The increasing of protein content in enriched muffin results, consequently, in increasing its nutritional quality, due to the quality of chickpea protein, compared to the control muffins $(89.47 \%)$.

The protein digestibility (\%) of chickpea protein in muffins is represented in figure (4). It is directly proportional to the enrichment percentage of protein isolate with scores of 91.44, 92.97, 93.40 and $94.08 \%$ for M1, M2, M3 and M4 respectively. Unlike other legume proteins, chickpea protein has been shown to have improved digestibility upon heating, which can be mainly ascribed to protein denaturation and inactivation of protease inhibitors (Carbonaro et al., 1997).

\subsection{Texture Profile Analysis (TPA) of muffins}

Table 5 illustrates the Texture Profile Analysis (TPA) of CPI-enriched muffins showing: hardness, cohesiveness, springiness, gumminess and chewiness parameters. Hardness, springiness and cohesiveness are crucial textural parameters for consumers (Shevkani \& Singh, 2014). Chickpea protein isolate enrichment resulted in a significant increase in hardness, gumminess and chewiness of produced muffins as a function of increasing levels of protein isolate substitution. These results could be referred to increased protein that starts crosslinking during batter preparation. The reason for that is mixed networks which form with proteins during baking based on hydrophobic interactions and S-S bonds, which determine volume and texture (Deleu, Wilderjans, Van Haesendonck, Brijs \& Delcour, 2016; Deleu, Wilderjans, Vanhaesendonck, Brijs \& Delcour, 2017). Moreover, different types of proteins can impact each other's network formation (Lambrecht, Rombouts, Nivelle \& Delcour, 2017).

\subsection{Sensory evaluation}

The mean sensory score of chickpea protein fortified muffins is illustrated in table 6. Muffin shape had a high acceptability score with up to $10 \%$ of protein isolate (similar to the shape of control, $100 \%$ wheat flour). The mouth feel of the product showed significant differences among control and all blends, with sensory score gradually decreasing with higher CPI inclusion; the score in control was (like very much) while in $10 \%$ CPI was (like moderately). The low score at high level of protein isolate in muffins might be due to the higher value of gumminess and chewiness of protein isolate compared with wheat flour. The muffin samples $(2.50,7.50$ and 10 $\%$ of protein isolate) showed a higher score in flavour, which resulted in good acceptance (like very much) for panelists. All blends of protein isolate had a score of 8.50 to 7.50 , in accordance with sensorial acceptance (like moderately). The supplemented muffins had a yellow reddish crust colour. It is clear from data, that crust colour of fortified muffins in the ratio range $(2.5 \%-10 \%$ CPI) had almost the same score (like very much), meaning that fortification of muffins with chickpea protein isolate didn't negatively affect the crust colour. The same trend in crust colour was obtained for crumb colour of fortified muffins. No significant differences among control and all blends; sensory score was the same (Like very much). The results presented in table 6 show the texture of crust and crumb, there are no significant differences among control and all blends from $2.5 \%$ to $10 \%$ CPI, which means that wheat flour can be substituted with chickpea protein isolates with up to $10 \%$ without any negative effect on 


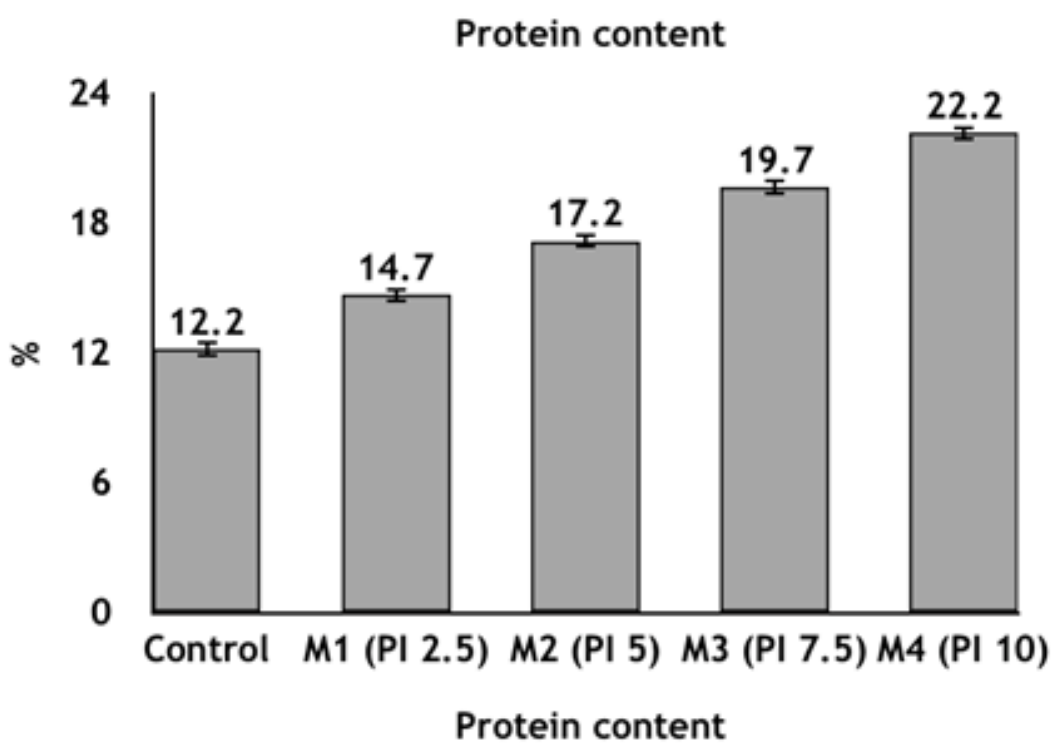

Figure 3: Protein content of enriched muffins. Data presented as mean \pm SD (samples were run in triplicate), ${ }^{\mathrm{a}, \mathrm{b}}$ Means followed by different superscript letters differ significantly $(p>0.05)$

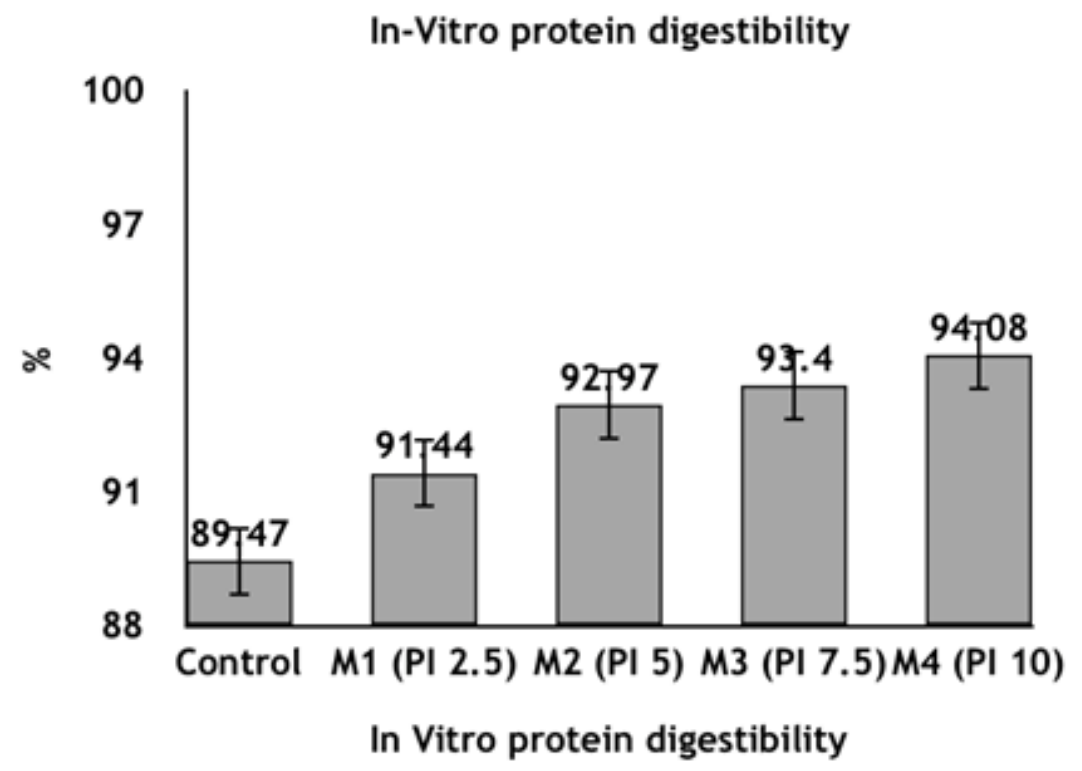

Figure 4: In Vitro protein digestibility of enriched muffins. Data presented as mean \pm SD (samples were run in triplicate), ${ }^{i, j}$ Means followed by different superscript letters differ significantly $(p>0.05)$ 
SI68 $\mid$ El-Sohaimy et al.

Table 5: Texture Profile Analysis (TPA) of chickpea protein enriched muffins

\begin{tabular}{lccccc}
\hline Sample & $\begin{array}{c}\text { Hardness } \\
(\mathbf{g})\end{array}$ & Cohesiveness & $\begin{array}{c}\text { Springiness } \\
(\mathbf{c m})\end{array}$ & $\begin{array}{c}\text { Gumminess } \\
(\mathbf{N})\end{array}$ & $\begin{array}{c}\text { Chewiness } \\
(\mathbf{g ~ c m})\end{array}$ \\
\hline Control & $176.67 \pm 19.66^{e}$ & $1.05 \pm 0.14^{a}$ & $1.02 \pm 0.08^{a}$ & $183.11 \pm 15.99^{e}$ & $187.05 \pm 20.44^{e}$ \\
M1 (CPI 2.5\%) & $180.00 \pm 10.00^{d}$ & $1.07 \pm 0.06^{a}$ & $1.05 \pm 0.06^{a}$ & $187.73 \pm 3.21^{d}$ & $196.16 \pm 8.71^{d}$ \\
M2 (CPI 5\%) & $200.00 \pm 10.00^{c}$ & $1.05 \pm 0.01^{a}$ & $1.00 \pm 0.00^{a}$ & $205.00 \pm 7.07^{c}$ & $205.00 \pm 7.07^{c}$ \\
M3 (CPI 7.5\%) & $213.33 \pm 11.55^{b}$ & $0.95 \pm 0.06^{a}$ & $1.00 \pm 0.00^{a}$ & $210.00 \pm 14.14^{b}$ & $210.00 \pm 14.14^{b}$ \\
M4 (CPI 10\%) & $296.67 \pm 32.15^{a}$ & $1.11 \pm 0.11^{a}$ & $1.00 \pm 0.00^{a}$ & $315.00 \pm 7.07^{a}$ & $315.00 \pm 7.07^{a}$ \\
\hline
\end{tabular}

Data presented as mean \pm SD (samples were run in triplicate),

Means in the same column followed by different superscript letters are significantly different $(\mathrm{p}>0.05)$

$\mathrm{CPI}=$ Chickpea protein isolate

Table 6: Sensory evaluation of chickpea protein enriched muffins

\begin{tabular}{lccccc}
\hline $\begin{array}{l}\text { Organoleptic } \\
\text { properties }\end{array}$ & Control & $\begin{array}{c}\text { M1 } \\
\mathbf{2 . 5 \%} \mathbf{C P I})\end{array}$ & $\begin{array}{c}\text { M2 } \\
\mathbf{( 5 \%} \mathbf{C P I})\end{array}$ & $\begin{array}{c}\text { M3 } \\
(\mathbf{7 . 5 \%} \mathbf{C P I})\end{array}$ & $\begin{array}{c}\text { M4 } \\
(\mathbf{1 0 \%} \mathbf{C P I})\end{array}$ \\
\hline Shape & $8.15^{a} \pm 0.63$ & $8.08^{a b} \pm 0.73$ & $8.00^{b} \pm 0.66$ & $7.80^{a b} \pm 0.84$ & $7.60^{a b} \pm 0.84$ \\
Mouth feel & $8.40^{a} \pm 0.70$ & $8.20^{a b} \pm 0.63$ & $7.80^{a b c} \pm 1.03$ & $7.80^{b c} \pm 0.79$ & $7.50^{b c} \pm 0.52$ \\
Flavor & $8.50^{a} \pm 0.70$ & $8.60^{a} \pm 0.70$ & $8.30^{a b} \pm 0.73$ & $8.00^{a b} \pm 0.67$ & $7.50^{b} \pm 0.85$ \\
Crust colour & $7.90^{a b} \pm 0.99$ & $7.70^{a b} \pm 1.16$ & $8.20^{a} \pm 0.73$ & $7.70^{a b} \pm 0.74$ & $7.45^{a b} \pm 0.95$ \\
Crust texture & $7.80^{a} \pm 0.92$ & $7.70^{a} \pm 0.82$ & $7.90^{a} \pm 0.92$ & $8.30^{a} \pm 0.73$ & $8.07^{a} \pm 0.96$ \\
Crumb colour & $8.70^{a} \pm 0.53$ & $8.20^{a} \pm 0.79$ & $8.10^{a} \pm 0.87$ & $7.80^{a} \pm 0.63$ & $8.04^{a} \pm 0.66$ \\
Crumb texture & $8.90^{a} \pm 0.71$ & $8.10^{a} \pm 0.74$ & $7.70^{a} \pm 1.33$ & $8.00^{a} \pm 0.47$ & $8.36^{a} \pm 1.05$ \\
Overall acceptance & $8.55^{a} \pm 0.49$ & $8.15^{a b} \pm 0.69$ & $7.73^{a b c} \pm 0.97$ & $7.79^{a b c} \pm 0.76$ & $7.47^{b c} \pm 0.33$ \\
\hline
\end{tabular}

Means in the same column followed by different superscript letters are significantly different $(\mathrm{p}>0.05)$

$\mathrm{CPI}=$ Chickpea protein isolate

the consumer perception of texture characteristics of muffins. The overall acceptance in control was $8.90 \pm 0.49$ while in $10 \%$ protein isolate was $8.36 \pm 0.57$. There is no reduction in overall acceptance in all blends with chickpea protein isolate and a high organoleptic score (from like moderately to like very much). The fortification of muffins with up to $10 \%$ chickpea protein isolate shows no negative effect on overall acceptance of the final product. These results agree with Herranz, Canet, Jose Jimenez, Fuentes and Dolores Alvarez (2016) who reveled that fortification of muffins with chickpea flour resulted in a chickpea like taste which was not a driver of disliking for the panelists.

\section{Conclusion}

The present study was designed to increase the nutritional and rheological properties of muffins by adding chickpea protein isolate in different blends (up to $10 \%$ ). Chickpea protein profile on SDS-PAGE revealed protein subunits with molecular weights of $(47,30$ and $85 \mathrm{kDa})$ in descending order, which could belong to globulin fractions, legumin-like and vicilin-like protein. Chickpea protein isolate (CPI) showed relatively high emulsifying activity index of $25.17 \mathrm{~m}^{2} \mathrm{~g}^{-1}$, emulsion stability index 14.09 min, foaming capacity $62 \%$ and foaming stability $94.49 \%$. Water and oil absorption scored 3.65 and $2.30 \mathrm{~mL}$ $\mathrm{g}^{-1}$, respectively. Chickpea protein isolate incorporation resulted in increases in hardness, gumminess and chewiness of baked muffins due to 
increasing protein concentration. Sensory evaluation showed consumer acceptance of enriched muffins where they achieved high scores. Since consumers enjoy baked food products; the fortification of muffins with up to $10 \%$ chickpea protein isolate has no negative effect on the overall acceptance of the final product. Our results encourage the employment of chickpea protein isolate as a vehicle to produce higher nutritional value products. More research is going on to achieve the maximum replacement of wheat flour with protein isolate and chickpea flour in muffins to develop a high nutritionally valued and glutenfree muffin that does not affect the rheological properties

\section{Acknowledgements}

Authors appreciate the support provided by, Wine, Food and Molecular Biosciences Department, Faculty of Agriculture and Life Sciences, Canterbury, New Zealand, to achieve this work.

\section{References}

Aguilar, V. \& Vélez-Ruiz, J. (2016). Characterization of two chickpea varieties and the effect of cooking on their physico-chemical and functional properties of flours. Journal of Food Research, 5, 67. doi:10.5539/jfr. v5n5p67

Alleoni, A. C. C. (2006). Albumen protein and functional properties of gelation and foaming. Scientia Agricola, 63, 291-298. doi:10. 1590/S0103-90162006000300013

Aloweidat, M. Y. (2014). Growth performance and yield components of five legume crops under rain-fed conditions.

Alvarez, M., Cuesta, F., Herranz, B. \& Canet, W. (2017). Rheometric non-isothermal gelatinization kinetics of chickpea flour-based gluten-free muffin batters with added biopolymers. Foods, 6, 3. doi:10 . 3390/ foods 6010003

AOAC. (1990). Official Methods of Analysis, 15th ed. Association of Official Analytical Chemists. INC., Arlig-ton, Virginia, USA.
Bhaduri, S. (2013). A comprehensive study on physical properties of two gluten-free flour fortified muffins. Journal of Food Processing and Technology, 04. doi:10.4172/ 2157-7110.1000251

Bodwell, C., Satterlee, L. \& Hackler, L. (1980). Protein digestibility of the same protein preparations by human and rat assays and by in vitro enzymic digestion methods1 2 . The American journal of clinical nutrition, 33, 677-86. doi:10.1093/ajcn/33.3.677

Bourne, M. (2002). Food texture and viscosity : Concept and measurement / m.c. bourne.

Boye, J., Aksay, S., Roufik, S., Ribéreau, S., Mondor, M., Farnworth, E. \& Rajamohamed, S. (2010). Comparison of the functional properties of pea, chickpea and lentil protein concentrates processed using ultrafiltration and isoelectric precipitation techniques. Food Research International, 43(2), 537-546. Molecular, Functional and Processing Characteristics of Whole Pulses and Pulse Fractions and their Emerging Food and Nutraceutical Applications. doi:https : / / doi .org / 10.1016/j . foodres.2009.07.021

Carbonaro, M., Cappelloni, M., Nicoli, S., Lucarini, M. \& Carnovale, E. (1997). Solubilitydigestibility relationship of legume proteins. Journal of Agricultural and Food Chemistry, 45(9), 3387-3394. doi:10.1021/ jf970070y. eprint: https://doi.org/10.1021/ jf970070y

Chandra, S. \& Samsher, a. (2013). Assessment of functional properties of different flours. African journal of agricultural research, 8, 4849-4852. doi:10.5897/AJAR2013.6905

Chang, Y.-W., Alli, I., Konishi, Y. \& Ziomek, E. (2011). Characterization of protein fractions from chickpea (cicer arietinum l.) and oat (avena sativa l.) seeds using proteomic techniques. Food Research International, 44(9), 3094-3104. doi:10.1016/j . foodres.2011.08.001

Deleu, L. J., Wilderjans, E., Van Haesendonck, I., Brijs, K. \& Delcour, J. A. (2016). Protein network formation during pound cake making: The role of egg white proteins and wheat flour gliadins. Food Hydrocolloids, 
61, 409-414. doi:10.1016/j.foodhyd.2016. 05.001

Deleu, L., Wilderjans, E., Vanhaesendonck, I., Brijs, K. \& Delcour, J. (2017). 15 n-labeling of egg proteins for studying protein network formation during pound cake making. Cereal Chemistry Journal, 94. doi:10.1094/ CCHEM-07-16-0183-R

Folch, J., Lees, M. \& Stanley, G. (1957). A simple method for the isolation and purification of total lipides from animal tissues. The Journal of biological chemistry, 226, 497509.

Gao, J., Brennan, M. A., Mason, S. L. \& Brennan, C. S. (2016). Effect of sugar replacement with stevianna and inulin on the texture and predictive glycaemic response of muffins. International Journal of Food Science and Technology, 51(9), 1979-1987. doi:10.1111/ijfs.13143

Gao, J., Brennan, M. A., Mason, S. L. \& Brennan, C. S. (2017). Effects of sugar substitution with "stevianna" on the sensory characteristics of muffins. Journal of Food Quality. doi:10.1155/2017/8636043

Herranz, B., Canet, W., Jose Jimenez, M., Fuentes, R. \& Dolores Alvarez, M. (2016). Characterisation of chickpea flour-based gluten-free batters and muffins with added biopolymers: Rheological, physical and sensory properties. International Journal of Food Science and Technology, 51(5), 1087-1098. doi:10.1111/ijfs.13092

Ihekoronye, A. I. \& Ngoddy, P. O. (1985). Integrated food science and technology for the tropics. (pp. 296-301). Macmillan. Retrieved from http : / / www . gproxx . com / http : / / blogxd . info / dspace / uk / integrated_food_science_and_ technology_for_the_tropics.pdf

Johnston, S. P., Nickerson, M. T. \& Low, N. H. (2015). The physicochemical properties of legume protein isolates and their ability to stabilize oil-in-water emulsions with and without genipin. Journal of Food Science and Technology - MYSORE, 52(7), 41354145. doi:10.1007/s13197-014-1523-3

Klompong, V., Benjakul, S., Kantachote, D. \& Shahidi, F. (2007). Antioxidative activity and functional properties of protein hydro- lysate of yellow stripe trevally (selaroides leptolepis) as influenced by the degree of hydrolysis and enzyme type. Food Chemistry, 102(4), 1317-1327. doi:10.1016/ j . foodchem.2006.07.016

Ladjal-Ettoumi, Y., Boudries, H., Chibane, M. \& Romero, A. (2016). Pea, chickpea and lentil protein isolates: Physicochemical characterization and emulsifying propertiesu. Food Biophysics, 11(1), 43-51. doi:10 . 1007/s11483-015-9411-6

Laemmli, U. K. (1970). Cleavage of structural proteins during assembly of head of bacteriophage-t4. Nature, 227(5259), 680+. doi:10.1038/227680a0

Lambrecht, M. A., Rombouts, I., Nivelle, M. A. \& Delcour, J. A. (2017). The role of wheat and egg constituents in the formation of a covalent and non-covalent protein network in fresh and cooked egg noodles. Journal of Food Science, 82(1), 24-35. doi:10.1111/ 1750-3841.13558

Liu, L. H., Hung, T. V. \& Bennett, L. (2008). Extraction and characterization of chickpea (cicer arietinum) albumin and globulin. Journal of Food Science, 73(5), C299C305. doi:10.1111/j.1750-3841.2008.00773. $\mathrm{X}$

O'Neil, E., Nicklas, A. \& Fulgoni III, V. L. (2014). Chickpeas and hummus are associated with better nutrient intake, diet quality, and levels of some cardiovascular risk factors: National health and nutrition examination survey 2003-2010. Nutrition \& Food Sciences.

Papalamprou, E. M., Doxastakis, G. I. \& Kiosseoglou, V. (2010). Chickpea protein isolates obtained by wet extraction as emulsifying agents. Journal of the Science of Food and Agriculture, 90(2), 304-313. doi:10.1002/jsfa.3816

Pearce, K. N. \& Kinsella, J. E. (1978). Emulsifying properties of proteins-evaluation of a turbidimetric technique. Journal of Agricultural and Food Chemistry, 26(3), 716723. doi:10.1021/jf60217a041

Rahman, R., Hiregoudar, S., Veeranagouda, M., Ramachandra, C. T., Nidoni, U., Roopa, R. S., .. Ganjyal, G. M. (2015). Effects of wheat grass powder incorporation on 
physiochemical properties of muffins. International Journal of Food Properties, 18(4), 785-795. doi:10 . $1080 / 10942912$. 2014. 908389

Rahman, R., Hiregoudar, S., Veeranagouda, M., C T, R., Kammar, M., Nidoni, U. \& R S, R. (2015). Physico-chemical, textural and sensory properties of muffins fortified with wheat grass powder. Karnataka J. Agric. Sci. 28, 79-82.

Shevkani, K. \& Singh, N. (2014). Influence of kidney bean, field pea and amaranth protein isolates on the characteristics of starch-based gluten-free muffins. International Journal of Food Science and Technology, 49(10), 2237-2244. doi:10.1111/ijfs. 12537

El-Sohaimy, S., Sitohy, M. \& El-Masry, R. (2007). Isolation and partial characterization of chickpea, lupine and lentil seed proteins. World Journal of Agricultural Sciences, 3, 123-129.

Tsutsui, T. (1988). Functional-properties of heat-treated egg-yolk low-density lipoprotein. Journal of Food Science, 53(4), 11031106. doi:10 . $1111 /$ j . $1365-2621$. 1988 . tb13539.x

Valmorida, J. S. \& Castillo-Israel, K. A. T. (2018). Application of plackett-burman experimental design in the development of muffin using adlay flour. In A. Albaarri (Ed.), International symposium on food and agro-biodiversity (isfa) 2017 (Vol. 102). IOP Conference Series-Earth and Environmental Science. 2nd International Symposium on Food and Agrobiodiversity (ISFA), Semarang, INDONESIA, SEP 26-27, 2017. doi:10.1088/17551315/102/1/012081

Wallace, T. C., Murray, R. \& Zelman, K. M. (2016). The nutritional value and health benefits of chickpeas and hummus. Nutrients, 8(12). doi:10.3390/nu8120766

Wardy, W., Jack, A. R., Chonpracha, P., Alonso, J. R., King, J. M. \& Prinyawiwatkul, W. (2018). Gluten-free muffins: Effects of sugar reduction and health benefit information on consumer liking, emotion, and purchase intent. International Journal of Food
Science and Technology, 53(1), 262-269. doi:10.1111/ijfs.13582 